\title{
Gene Expression of Erythropoietin in Renal Cell Carcinoma
}

\author{
Yumi Noguchi, Tatsuro Goto, Yuji Yufu, Naokuni Uike, Yoshihiro HasegawA*, Toshiro FukudA**, \\ Atsuo $\mathrm{JIMI}^{* * *}$ and Akihiro FunAKOSHI $* * * *$
}

\begin{abstract}
A 57-year-old man with renal cell carcinoma and erythrocytosis showed a high serum level of erythropoietin (EPO). High EPO signal was observed on Northern blot analysis and RT-PCR in the total RNA extracted from the renal tumor. Immunohistochemical staining also demonstrated tumor tissue with high immunostaining of EPO. Nucleotide sequences of EPO cDNA in the tumor were normal. To date, only one report has discussed the nucleotide sequences of a tumor's EPO gene; it showed mutant EPO cDNA in hepatocellular carcinoma tissue. This is the first demonstration of normal EPO cDNA in renal cell carcinoma.

(Internal Medicine 38: 991-994, 1999)
\end{abstract}

Key words: erythrocytosis, PCR, mRNA

\section{Introduction}

Erythropoietin (EPO), a glycoprotein produced mainly by the kidney, controls erythropoiesis (1). Increased EPO production results in secondary erythrocytosis, which has been reported in a variety of tumors including renal cell carcinoma (1), hepatocellular carcinoma (2), and cerebellar hemangioblastoma (3). There have, however, been few studies of gene expression or protein synthesis of EPO in tumor tissues (1-3). Here, in a case of renal cell carcinoma with erythrocytosis, we demonstrate the increased expression of EPO mRNA in the tumor tissue by reverse transcriptase-polymerase chain reaction (RT-PCR) and Northern blot analysis, and detect the EPO protein by immunostaining. Previously, we have reported the mutant EPO cDNA in hepatocellular carcinoma tissue (4). In this study, we also analyzed the nucleotide sequences of the EPO cDNA in normal and tumor tissues.

\section{Case Report}

\section{Patient and method}

A 57-year-old Japanese man was admitted to our hospital to be examined for erythrocytosis. Physical examination was unremarkable. A blood examination showed RBC $7.89 \times 10^{12} / l, \mathrm{Hb}$ 20.4 g/dl, Ht 65\%, (MCV 82.4 fl, MCH 25.9 pg, MCHC 31.4 $\mathrm{g} / \mathrm{dl}$ ). His WBC count was $5.02 \times 10^{9} / l$ and his platelet count was $19.4 \times 10^{10} / l$. Serum iron $(97 \mu \mathrm{g} / \mathrm{dl})$, TIBC $(317 \mu \mathrm{g} / \mathrm{dl})$, and ferritin $(220 \mu \mathrm{g} / \mathrm{dl})$ were all normal. His serum erythropoietin
(EPO) level was $80.2 \mathrm{mU} / \mathrm{ml}$ (normal range $8-36 \mathrm{mU} / \mathrm{ml}$ ) with a high level of LDH at $396 \mathrm{IU} / l$ (normal range 206-370 IU/l). Analysis of arterial blood gas was normal. The bone marrow aspirate sample was normocellular with a low myeloid/erythroid ratio (1.10), and chromosomal analysis revealed normal 46, XY. Abdominal ultrasound sonography and computerized tomographic (CT) scan demonstrated a massive lesion in the lower side of the left kidney (Fig. 1A). Angiography demonstrated a hypervascular tumor of the left kidney (Fig. 1B). The radiographic appearance was consistent with left renal cell carcinoma. One month later, a left nephrectomy with splenectomy was done. The patient had an uneventful postoperative course. Histological examination of the tumor showed renal cell carcinoma, of predominantly the clear cell subtype, which was proliferated in an alveolar pattern (Fig. 2).

One month after the operation, the patient's serum EPO levels returned to normal $(9.9 \mathrm{mU} / \mathrm{ml})$ and erythrocytosis was

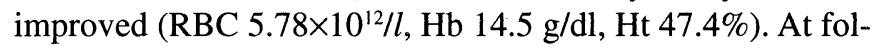
low up 5 months later, he remained clinically well and the CT scan showed no recurrence.

\section{Gene expression of erythropoietin}

RT-PCR followed by Southern blot analysis

Total RNA was extracted from the surgical specimen by the GTC (guanidinium thiocyanate)- $\mathrm{CsCl}$ (cesium chloride) method. cDNA was synthesized from $5 \mu \mathrm{g}$ of total RNA with AMV (avian myeloblastosis virus) reverse transcriptase. The oligonucleotide primers used for PCR of EPO cDNA were as

From the Department of Hematology, *the Department of Urology, **the Department of Pathology, ****the Department of Gastroenterology, National Kyushu Cancer Center Hospital, Fukuoka and ***the First Department of Pathology, Kurume University, Kurume

Received for publication November 11, 1998; Accepted for publication July 12, 1999

Reprint requests should be addressed to Dr. Yumi Noguchi, the Department of Hematology, National Kyushu Cancer Center Hospital, 3-1-1 Notame, Minamiku, Fukuoka 811-1395 


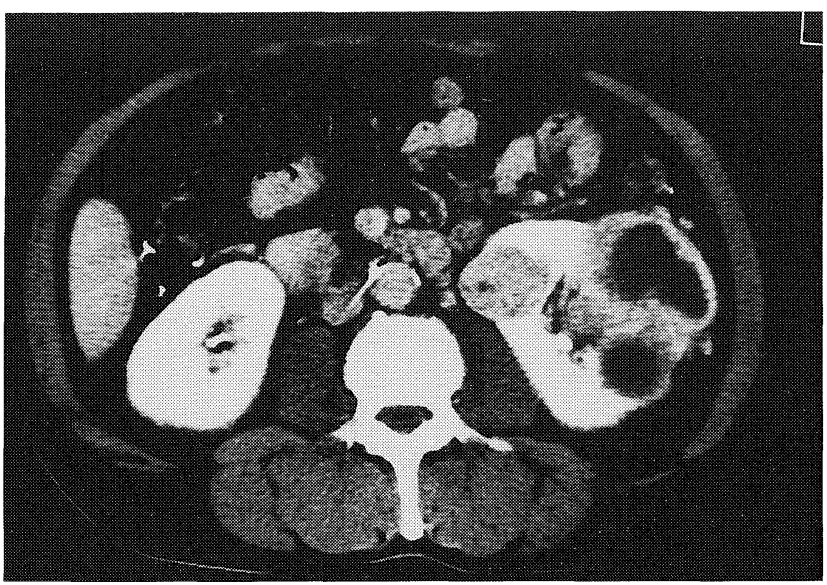

A

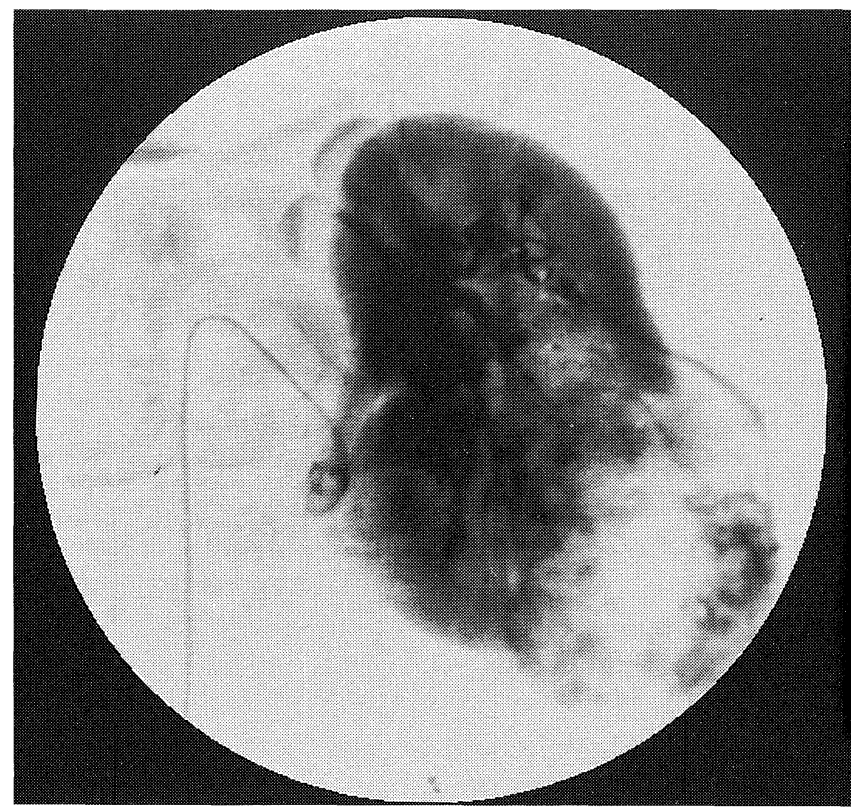

B

Figure 1. (A) The abdominal CT scan shows an irregularly enhanced mass in the lower side of the left kidney. The central area is poorly enhanced, indicating a central necrosis. (B) Angiography of the left kidney reveals a vascular tumor.

follows. The sense primer, which corresponded to the nucleotide sequence of the human EPO cDNA was 5'ATATCACTGTCCCAGACACC-3' (nucleotide 193-213). The anti-sense primer was $5^{\prime}$-AGTGATTGTTCGGAGTGGAG$3^{\prime}$ (nucleotide 464-483) (5). We used $\beta$-actin cDNA as an internal standard. The sense primer of $\beta$-actin was $5^{\prime}$ CTTCTACAATGAGCTGCGTG-3', and the anti-sense primer 5'-TCATGAGGTAGTCAGTCAGG-3' (4). Cycles were carried out at $94^{\circ} \mathrm{C}$ for 5 minutes; $94^{\circ} \mathrm{C}$ for $30 \mathrm{sec}$ onds; $55^{\circ} \mathrm{C}$ for 30 seconds; $72^{\circ} \mathrm{C}$ for 30 seconds $(40$ cycles for $\mathrm{EPO}$ and 20 cycles for $\beta$-actin); and, finally, at $72^{\circ} \mathrm{C}$ for

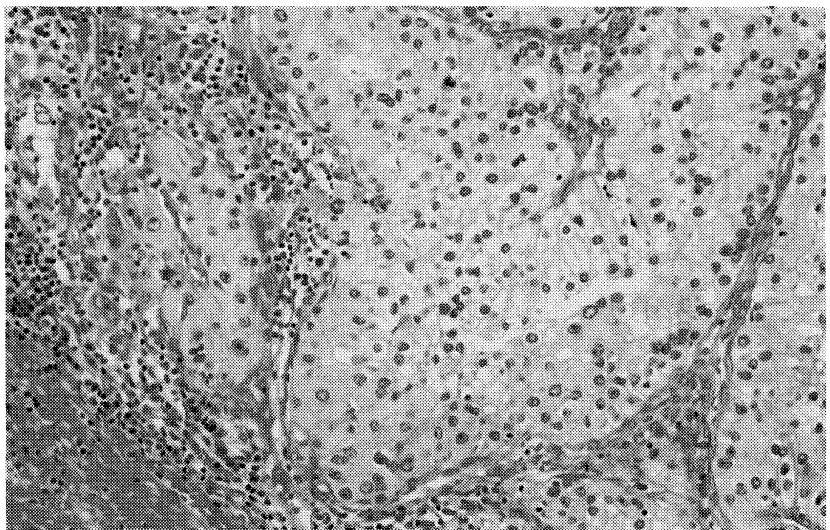

Figure 2. Histopathology of the renal tumor revealed renal cell carcinoma, clear cell subtype (HE stain, $\times \mathbf{4 0 0}$ ).

5 minutes. The PCR reaction product was separated electrophoretically in an agarose gel and blotted onto a nylon membrane. The blot was hybridized with a $\left[{ }^{32} \mathrm{P}\right]$-labelled oligonucleotide probe of the human EPO (5'GCAGCTGCATGTGGATAAAGCCGTCAGTGG-3') or human $\beta$-actin cDNA (4) at $37^{\circ} \mathrm{C}$, washed with decreasing concentrations of SSC to a final concentration of $0.1 \times \mathrm{SSC}, 0.1 \%$ SDS at $65^{\circ} \mathrm{C}$, and then auto-radiographed.

Determination of the nucleotide sequence of the amplified DNA

We identified the 290-bp region of amplified cDNAs from normal and tumor tissues by isolating them from agarose and determining their nucleotide sequences. Sequencing and analysis were carried out with an ABI TaqDydeoxy Terminator Cycle Sequencing Kit (Perkin-Elmer Biosystems Japan, Urayasu) and an Applied Biosystems Model 373 A DNA Sequencing System (Perkin-Elmer Biosystems Japan, Urayasu) (4).

\section{Northern blot analysis}

PolyA RNAs were isolated with an oligo dT column (Oligotex dT30, TAKARA, Tokyo). mRNA (700 ng) was separated on a $1 \%$ agarose gel after denaturation in $1 \mathrm{M}$-glyoxal, transferred to a nylon membrane (Zeta-probe, Bio-rad, Hercules CA USA) and then hybridized with [ $\left.{ }^{32} \mathrm{P}\right]$-labelled-cDNA probes of the human EPO and G3PDH cDNA (4). Hybridization was performed at $42^{\circ} \mathrm{C}$ for 20 hours in a solution of $50 \%$ formamide, $5 \mathrm{XSSC}, 20 \mathrm{mmol} / \mathrm{l} \mathrm{NaPO}_{4}(\mathrm{pH} 6.5$ ), $0.2 \% \mathrm{SDS}$, 2X Denhart's solution, $5 \%$ dextran sulfate and $200 \mathrm{mg} / \mathrm{ml}$ of denatured salmon sperm DNA.

\section{Immunohistochemical staining}

Tissues were fixed in 10\% formalin and embedded in paraffin. Sections of $5 \mu \mathrm{m}$ thickness were incubated with antiserum to human EPO (6) at dilutions of 1:100 to 1:500, and stained by the avidin-biotin peroxidase complex method. 


\section{Results}

\section{EPO mRNA determination}

We obtained two amplified DNAs from RNAs of the tumor

A

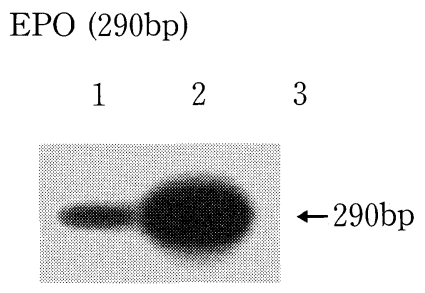

Figure 3. RT-PCR of mRNA from the normal kidney tissue (lane 1) and the renal cell carcinoma (lane 2). Lane 3: blank control. A: EPO cDNA. B: $\beta$ actin.

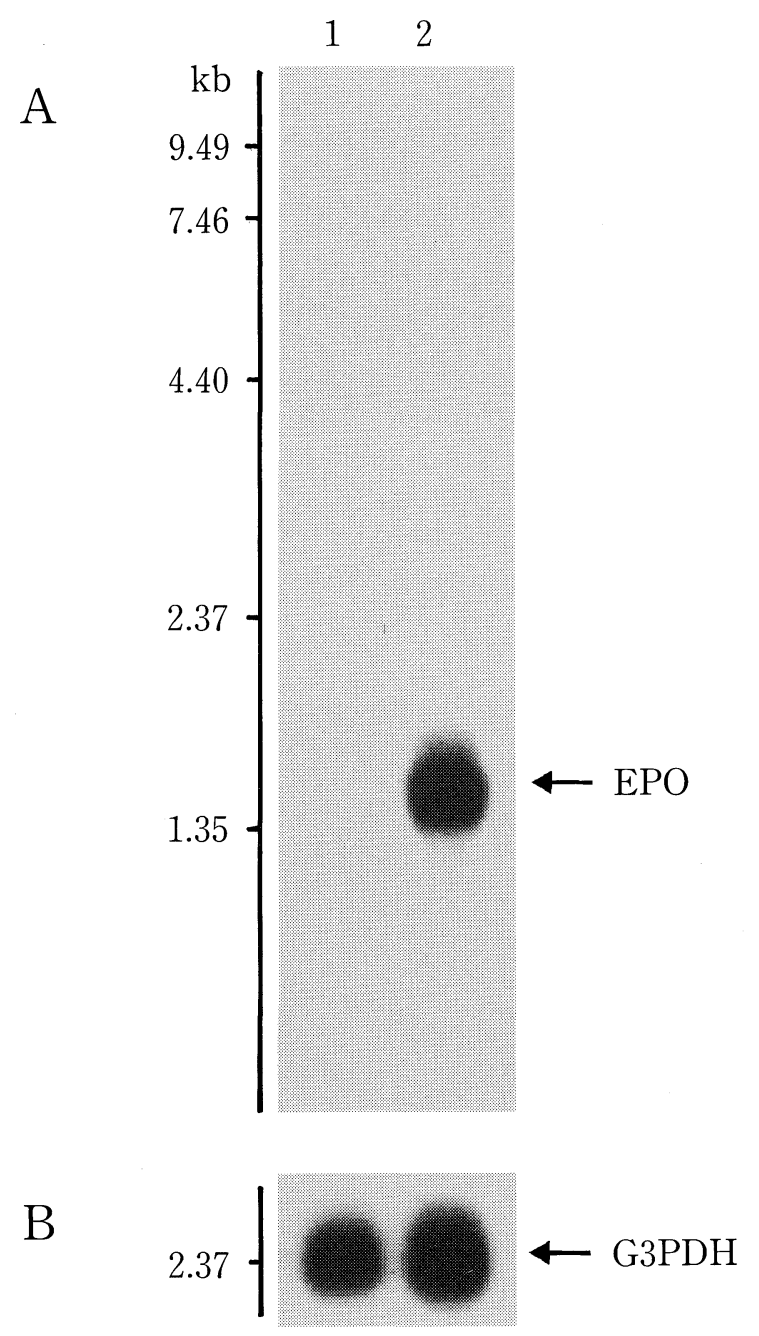

Figure 4. Northern blot analysis of EPO and G3PDH mRNAs from normal kidney tissue (lane 1) and tumor (lane 2). tissue and normal kidney, which corresponded to the expected size of 290 for EPO and 305 base pairs for $\beta$-actin (Fig. 3). Northern blot analysis of mRNA in the tumor showed a positive hybridization signal with human EPO cDNA probe (Fig. 4). In the nontumoral renal tissue, no EPO message could be detected, although a similar total amount of RNA was transferred to the filters, as demonstrated by hybridization with G3PDH.

\section{Immunohistochemical studies}

Positive cytoplasmic staining was observed with anti- EPO antibodies (Fig. 5A) in tumor tissue, but not in normal kidney tissue (Fig. 5B).

\section{Nucleotide Sequence}

The nucleotide sequences of the amplified cDNA of the tumor and normal renal tissue showed no differences from those

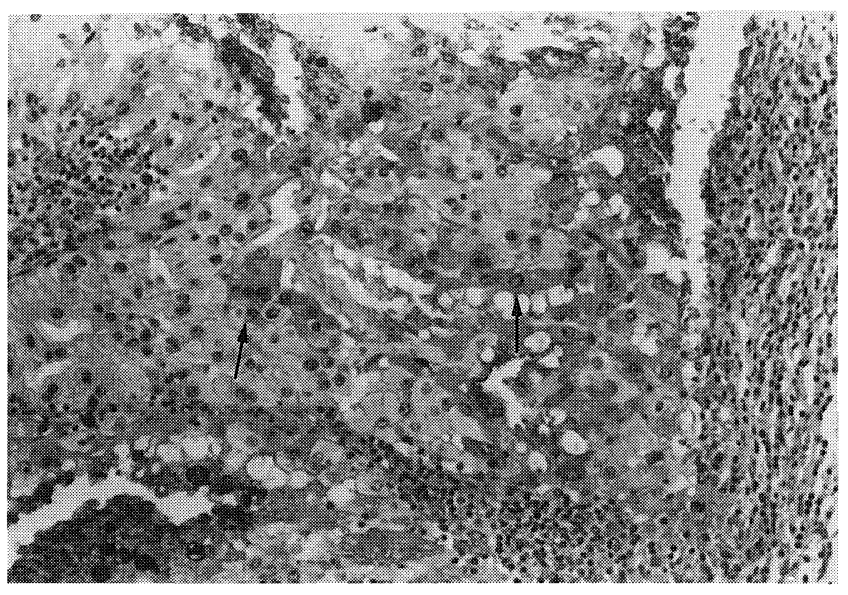

A

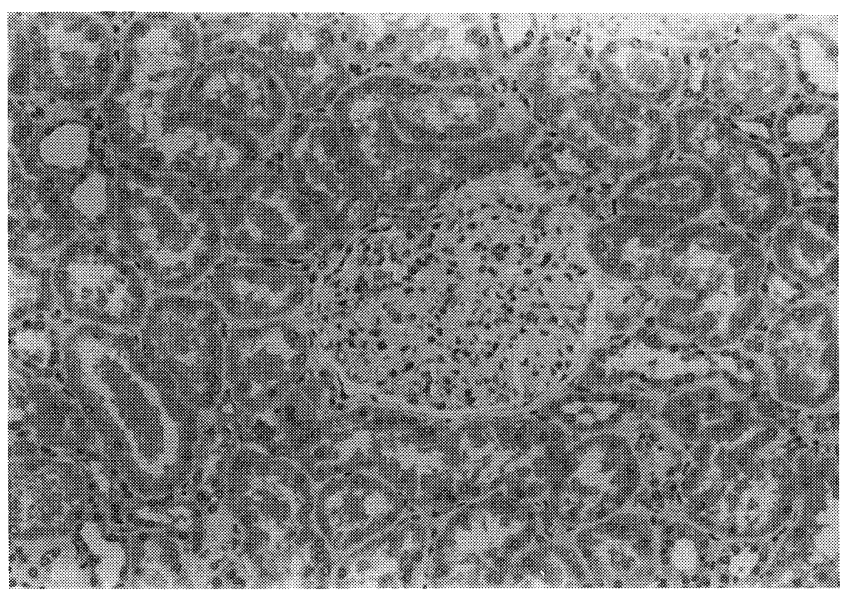

$\mathrm{B}$

Figure 5. Immunohistochemical staining of the tumor tissue section (A) and a normal kidney tissue section (B) with anti-erythropoietin antibody $(\times 100)$. Tumor cells exhibit cytoplasmic staining (arrows). 
of the EPO precursor cDNA reported by Jacobs et al (5).

\section{Discussion}

Few reports discuss detection of EPO mRNA in the tumor from an erythrocytotic patient. Da Silva et al reported three cases of renal cell carcinoma with polycythemia (1). In their report, the EPO mRNA of the tumor seemed to be of normal size and no EPO gene rearrangement was observed. Muta et al reported on a hepatocellular carcinoma with polycythemia; Northern blot analysis showed the tumor's EPO mRNA to be the same size as that of normal EPO mRNA (2). The present study, using RT-PCR and Northern blot analysis, confirmed the increased expression of EPO mRNA in the tumor tissue from the kidney. Immunohistochemical staining also revealed the production of EPO protein in the tumor tissue.

We have reported the nucleotide sequence of cDNA in tumor tissue in 1993, and showed mutant EPO mRNA expressions which produce bioactive mutant EPO protein in hepatocellular carcinoma tissue (4). There were three differences from those in the reported sequences of normal $\operatorname{EPO} \operatorname{cDNA}(4,5)$; however, the substitutions of the amino acids had no effect on biological activity. In our case, the nucleotide sequences of cDNA in tumor tissue were normal. These results show that there are normal and mutant EPO tumor genes, both biologically active.

Expression of the EPO gene is under the control of cis-acting sequences located at $5^{\prime}$ and $3^{\prime}$ to the gene (7). The up-regulation of EPO gene translocation by hypoxia is mediated by hypoxia-inducible factor-1 (HIF-1) and hepatic nuclear factor4 (HNF-4), which bind to cognate response elements in a $3^{\prime}$ enhancer (8). C-terminal portion of HIF-1 specifically binds to p300 and overexpression of p300 enhances hypoxic induction (7). It is possible that a change in the transcription factor or a mutation in the promoter may influence the level of EPO gene expression in patients with erythrocytosis. In our case, analysis of HIF-1 and HNF-4 has not been done. Further investigation of the hypoxia-responsive element and EPO gene in patients with erythrocytosis is needed.

\section{References}

1) Da Silva JL, Lacombe C, Bruneval P, et al. Tumor cells are the site of erythropoietin synthesis in human renal cancers associated with polycythemia. Blood 75: 577-582, 1990.

2) Muta H, Funakoshi A, Baba T, et al. Gene expression of erythropoietin in hepatocellular carcinoma. Intern Med 33: 427-431, 1994.

3) Trimble M, Caro J, Talalla A, Brain M. Secondary erythrocytosis due to a cerebellar hemangioblastoma: demonstration of erythropoietin mRNA in the tumor. Blood 78: 599-601, 1991.

4) Funakoshi A, Muta H, Baba T, Shimizu S. Gene expression of mutant erythropoietin in hepatocellular carcinoma. Biochem Biophys Res Commun 195: 717-722, 1993.

5) Jacobs K, Shoemaker C, Rudersdorf R, et al. Isolation and characterization of genomic and cDNA clones of human erythropoietin. Nature 313: 806-810, 1985.

6) Matsubara K, Yoshimura T, Kamachi S, Fukushima M, Hino M, Morii H. Radioimmunoassay for erythropoietin using anti-recombinant erythropoietin antibody with high affinity. Clin Chim Acta 185: 177-184, 1989.

7) Lacombe C, Mayeux P. Biology of erythropoietin. Haematologica 83: 724-732, 1998.

8) Bunn HF, Gu J, Huang LE, Park JW, Zhu H. Erythropoietin: A model system for studying oxygen-dependent gene regulation. J Exp Biol 201: 1197-1201, 1998. 